Teller, Christoph, Elms, Jonathan R.. 2011. Urban Place Marketing and Retail Agglomeration Customers. Journal of Marketing Management, in print, DOI: 10.1080/0267257X.2010.517710.

\title{
Urban Place Marketing and Retail Agglomeration Customers
}

Christoph Teller ${ }^{\dagger}$, Jonathan Elms ${ }^{\dagger \dagger}$

Institute for Retail Studies, University of Stirling, Stirling, Scotland, United Kingdom

$\lceil\ldots$ [corresponding author] Institute for Retail Studies, University of Stirling, Stirling. FK9 4LA. Scotland, United Kingdom. Tel: +44 (0) 1786 466454; Fax: +44 (0) 1786465290. Email: christoph.teller@stir.ac.uk.

$\dagger \dagger \ldots$ Institute for Retail Studies, University of Stirling. Stirling. FK9 4LA. Scotland, United Kingdom. Tel: +44 (0) 1786 467375; Fax: +44 (0) 1786464745.

Email: j.r.elms@stir.ac.uk. 


\title{
Urban Place Marketing and Retail Agglomeration Customers
}

\begin{abstract}
Through identifying the attributes of a place that have an influence on the patronage behaviour of urban retail customers, this paper presents a conceptual model that proposes direct and indirect antecedents regarding the different retail-related dimensions associated with urban place attractiveness. An empirical study was conducted whereby the model was tested by surveying approximately five hundred actual consumers at the time they visited a particular town centre for the purposes of shopping. The results showed that the retail tenant mix, the merchandise value and the atmosphere had a direct impact and the product range and the sales personnel an indirect impact upon the evaluation of attractiveness. Furthermore, a number of additional effects towards these antecedents were identified with respect to parking conditions, the non retail tenant mix, manoeuvrability and orientation. This revealed that retailing activities were a major driver of attractiveness for an urban place. The practical implication of these findings suggests that place marketing activities should be proactive in supporting and enabling retailers in fulfilling their roles.
\end{abstract}

\section{Keywords}

Place Marketing, Retail Agglomeration, Town Centre, Place Users, Retail Patronage

\section{Biographies}

Christoph Teller is a senior lecturer in marketing based in the Institute for Retail Studies, Stirling Management School, University of Stirling. He was previously assistant professor at the Vienna University of Economics and Business. Christoph's research interests are in the area of store (format) and agglomeration (format) choice/patronage, retail logistics and webbased research methodologies.

Jonathan Elms is a lecturer in marketing based in the Institute for Retail Studies, Stirling Management School, University of Stirling. He was previously a teaching fellow at Lancaster University Management School. Jonathan's research interests fall under the umbrella of retail change and the socio-spatial contexts of consumption. 


\section{Urban Place Marketing and Retail Agglomeration Customers}

\section{Introduction}

Retail agglomerations are an omnipresent feature of the urban environment in both developed and developing nations and, as such, are an important element of the urban "place product" (Whyatt, 2004; Short \& Kim, 1998). As 'landscapers of cities' retailers have an influence on how attractive place users perceive an urban place to be (Warnaby \& Davies, 1997). Not only are store clusters a reaction to the increasing competition that exists amongst urban places, such as districts, towns and cities (Teller \& Reutterer, 2008), but they function as attractors for multiple, yet heterogeneous, place user groups - for example, prospective and existing residents, tourists, visitors, consumers and employees (Shaw \& Williams, 1992). In contrast to created agglomerations, which are the product of an explicit process of planning and design such as shopping centres often located on the outskirts of cities or towns, evolved retail agglomerations - encompassing shopping streets and other kinds of (urban) store clusters are an integral part of the urban fabric. However, they exist in an environment not purposely built for the requirements of retailers and their consumers (Teller, 2008). Consequently, to market an urban environment - which retail agglomerations are an integral part of - it is crucial to understand a place's characteristics relative to its competitors and to identify the different place user groups that inhabit it (Hospers, 2006).

Concurrently, place marketing strategies and activities, as part of the "place formation process" (Aiesha, 2006), must be directed and focussed towards specific place user groups in order to better ensure commercial success (Madsen, 1992). Thus, in turn, place marketers need to know why their place is seen to be attractive compared to others from a place user's point of view (Skinner, 2008). Insch and Florek (2008) note that the nature of "place satisfaction" needed to be better understood. This is particularly pertinent for those place users who patronise a specific urban environment, i.e. actual shoppers - those consumers who 
express some degree of loyalty and/or preference towards a particular urban environment - as well as the retail agglomerations located there. For place marketers this user group should be of primary concern since (1) it is much more expensive to attract new consumers than to retain existing ones; (2) they are or can become important promoters of a place in terms of word of mouth, and; (3) this place user group has credibility in how they have reached a judgment regarding the antecedents of attractiveness in that they reside in that urban environment (e.g. Reichheld, 2001).

To date, however, the place marketing literature has tended to favour the "place product" supplier or managers' view (Gower, 2008). This has resulted in a lack of understanding of the antecedents of attractiveness of urban places from a place user's perspective, in general, and the actual shopper's point of view, in particular (Warnaby et al., 2005). Conversely, retail research has incorporated the place user perspective but primarily in terms of purpose built places - that is created agglomerations - rather than those that have evolved organically over time (Teller, 2008). Indeed, only a few authors have dealt with retail agglomerations within urban places from a consumer's point of view but with this being undertaken through the focus of retail managers (Teller \& Elms, 2010). Nevertheless, competition between and attractiveness of urban retail areas on an aggregated level has been considered in older publications often informed by spatial interaction theory, as well as by more recent articles where multiplicative competitive interaction models have been used (for literature review see Teller \& Reutterer, 2008).

Accordingly, in this paper we address, firstly, this theoretical myopia in the extant literature and secondly, the practical importance of understanding why actual shoppers patronise an urban environment and how this then suggests how a place should successfully market its retail offering. Consequently, we focus our attention on the following two research objectives: 
(1) to identify the retail related attributes of an urban place from the extant literature, and; (2) to evaluate the relative importance of each attributes with respect to the attractiveness of an urban place. In attempting to achieve these objectives, we reveal and gain insights into those areas and instruments that place marketers need to prioritise in order to change perceptions, attitudes and behaviour amongst their place user groups.

This paper is structured as followed: after these introductory remarks, we discuss the concept of (retail related) attractiveness of urban places. We then identify the retail related place attributes that place marketers directly or indirectly manage and which contribute to the attractiveness of an urban retail agglomeration. This is followed by the presentation of a conceptual model where we propose effects between agglomeration attributes and dimensions of attractiveness. Thereafter, the research design of an empirical study is presented. The results are then described and discussed with reference to the extant literature, in particular the concept of urban place marketing. Finally, we present the major limitations of our findings and suggest directions for further research.

\section{The Attractiveness of Retail Agglomerations in Urban Places}

Like created retail agglomerations, store clusters within urban places generate agglomeration effects (Teller et al., 2008). These synergistic effects are due to outlets being nearby to one another and this can lead to benefits for both retailers and consumers (Schnedlitz \& Teller, 2008; Oppewal \& Holyoake, 2004). Retailers located in urban retail agglomerations can use infrastructural services that they do not have themselves (Teller \& Elms, 2010). These include parking facilities, the traffic infrastructure, provision of cash dispensers, public toilets, etc. More importantly retailers benefit from customer streams which occur naturally within an urban place, such as residents, tourists or employees. In general an agglomeration's customer streams are not generated by any store acting alone; rather they are the consequence of this process of clustering (Teller, 2008). In other words retailers intentionally cooperate in order to 
gain a larger share of consumer visits to agglomerations within their relevant choice set (Howard, 1997). Nevertheless, they also compete with each other regarding the share of spending, share of visits and share of time enjoyed by that agglomeration relative to other shopping locations (Teller \& Reutterer, 2008). Thus retailers can be seen simultaneously as 'hosts', in terms of being the main attractors for an urban place, but also as 'parasites' that exploit the existing infrastructure and the streams of customers together with those generated by other retailers or attractions within or around the urban retail agglomeration (Schnedlitz \& Teller, 2008). From a consumer's perspective, urban retail agglomeration can be used to conduct multi-purpose trips (e.g., Reimers \& Clulow, 2004; 2009; Baker, 1996). These trips not only include satisfying bundles of wants and needs at one place, but also spending their leisure time (eating, drinking and entertainment), meeting or visiting other people who live there or using other services offered by banks, non retail businesses or even the council administration. All the mentioned retail related attributes of urban retail agglomerations underpin the attractiveness of such places for consumers.

In this context, the term 'attractiveness' can be understood in a literal sense from its Latin origins (attraho 3, atraxi, attractus) and consequently interpreted as the degree by which consumers are drawn or pulled towards a particular urban place and a retail agglomeration manifested in their perceptions, attitudes and patronage behaviour. Thus attractiveness can be understood as an outcome of a holistic evaluation of perceived place attributes (Finn \& Lourviere, 1996). The multi-faceted latent construct of attractiveness can be operationalised by at least three latent factors (Teller \& Reutterer, 2008). According to Severin et al. (2001) and Ruiz et al. (2004), the first dimension is satisfaction with the agglomeration. It can be measured by the overall satisfaction with the agglomeration, by the extent to which it meets consumers' expectations and the degree to which an agglomeration meets an ideal place in the mind of individual consumer. The second dimension is retention proneness at the time the 
agglomeration is visited. This accounts for the intention to stay at the agglomeration as long as possible, the level of enjoyment of being there and the number of things planned to do there (Baker et al., 2002; Wakefield \& Baker, 1998). The final measure is patronage intention which can be described by the willingness to recommend the agglomeration to other people, to revisit it and spend money there in the future (Whyatt, 2004). In other words these three dimensions can be understood as the overall aims of place, agglomeration and retail managers/marketers to meet their consumers' needs and wants (satisfaction) in order to make them stay (retention proneness) and to return in the future (patronage intention) (Teller \& Elms, 2010). The proposed measures of attractiveness consequently have an impact on actual consumer behaviour in particular in terms of the share of spending, share of time and share of choice/visits of consumers dedicate to an agglomeration relative to other agglomerations, retail locations or places in general (Finn \& Lourviere, 1996).

\section{Conceptual Model}

In order to identify those attributes that are proposed to affect the retail related attractiveness of urban places we set up the following conceptual model which is embedded in the overall framework of Finn and Lourviere (1996) and Teller and Reutterer (2008). It can be denoted as a Stimulus-Organism-Response model (Mehrabian \& Russel, 1974) and proposes that patronage behaviour in urban retail agglomerations is affected by the evaluated attractiveness of the site (Response). The attractiveness, in turn, is affected by agglomeration attributes perceived by place users (Organism). The perception of attributes and the evaluation of the attractiveness can be influenced by the place or agglomeration management when applying marketing instruments (Stimuli). Based on that framework and the existing literature on agglomeration (format) patronage the following attributes are proposed to affect the attractiveness of urban retail agglomerations and places (Whyatt, 2004; see $x_{\mathrm{n}}$ and Figure 1). 


\section{The location of urban retail agglomerations}

In order to satisfy the defined wants and needs in an urban retail agglomeration, the spatial and temporal distance between points of origin - chiefly the household or the working place and the store(s) need to be overcome. The factor characterising how a place can be reached, i.e. accessibility, includes at least three dimensions which comprise the convenience of getting there $\left(x_{11}\right)$, the speed of access $\left(x_{12}\right)$ and the obstacles on the way $\left(x_{13}\right)$ (e.g., Alzubaidi \& Vignali, 1997; Wakefield \& Baker, 1998). The spatial and temporal distance between the starting point of the shopping trip (e.g. the home) and the agglomeration is also represented by these three perceptional measures $\left(x_{11}-x_{13}\right)$ and thus treated as a sub-dimension of accessibility. The rationale for not including distance as a separate attribute is that this factor is substantially affected by the shopping situation and thus varies depending on the point of origin of the shopping trip, the mode of transport used and the traffic conditions en route (Teller \& Reutterer, 2008). Additionally it is difficult to capture the perceptional dimensions of distance since consumers often have difficulties in precisely articulating the logistics of their shopping efforts into measures such as metres and minutes (Teller et al., 2006). By following the notions of Reimers and Clulow (2004; 2009) or Arentze and Timmermans (2001) we propose that the more general factor accessibility as an antecedent of attractiveness. We therefore derive the following hypothesis:

$\mathrm{H}_{11}$ : The accessibility $\left(\xi_{1}\right)$ positively affects attractiveness $\left(\eta_{1}\right)$ of an urban retail agglomeration.

Due to the strong importance of the car as a means of transport when shopping, parking conditions are a relevant attribute of an urban place. This characteristic can be described by the number of parking lots available $\left(x_{21}\right)$, by the variety of different parking facilities $\left(x_{22}\right)$ and by the degree to which the agglomeration is accessible from the parking lots, i.e. convenient $\left(x_{23}\right)$, quickly $\left(x_{24}\right)$ and without obstacles $\left(x_{25}\right)$ (e.g., Ruiz et al., 2004; van der 
Waerden et al., 1998). Parking conditions are, consequently, a sub-dimension of the overall level of accessibility. In terms of urban places, these two factors can be seen as a source of disadvantage compared to created retail agglomerations because the accessibility in general and the requirements of car borne customers are considered in the layout of e.g. shopping malls or strip centres. According to the notions of e.g. Leo and Philippe (2002), Tang et al. (2001) or Van der Waerden et al. (1998) the following hypothesis can be set up:

$\mathrm{H}_{12}$ : The parking conditions $\left(\xi_{2}\right)$ positively affect attractiveness $\left(\eta_{1}\right)$ of an urban retail agglomeration.

(Retail and non retail) Offer of urban retail agglomerations

These attributes characterise the degree to which consumers can satisfy their wants and needs. Overall, this accounts for the set of retail stores located in the urban place. This retail tenant mix $\left(\xi_{3}\right)$ can be described by the range $\left(x_{31}\right)$, the attractiveness $\left(x_{32}\right)$ and the number of wellknown stores $\left(x_{33}\right)$ (e.g., Dellaert et al., 1998; Prendergast et al., 1998). The retail offer of the tenants can be characterised, firstly, by the merchandise value offered with this being operationalised by the overall price level $\left(x_{41}\right)$, the quality level $\left(x_{42}\right)$ and the price-quality ratio $\left(x_{43}\right)$ (e.g., Severin et al., 2001; van Kenhove et al., 1999). Secondly, the choice of products offered by the tenants - product range - in terms of breadth $\left(x_{51}\right)$ and depth $\left(x_{52}\right)$ and range of brands available $\left(x_{53}\right)$ - is another characteristic of the retail offer (e.g., Oppewal \& Holyoake, 2004; Baker et al., 2002; Eastlick \& Feinberg, 1999). Finally, the sales personnel described by friendliness $\left(x_{61}\right)$, competency $\left(x_{62}\right)$ and readiness to help $\left(x_{63}\right)$ can be a determinant attributes of the retail face of an urban place (e.g., Ruiz et al., 2004; Hackett \& Foxall, 1994; Bearden, 1977). Compared to other retail locations, the retail offering of an urban place has a degree of uniqueness. Since the building structures in these urban places may not have been purposely built for modern large scale retailing, a considerable number of stores are of a smaller size and may be operating as speciality stores. Consequently, sales 
service, high quality products and deep assortments are typical characteristics of these urban retail agglomerations. However, regardless of this, the retail offering has evolved in an unguided and unplanned manner.

Since a considerable number of authors have identified these factors as drivers of retail related attractiveness we present the following hypotheses (Teller \& Reutterer, 2008; Anselmsson, 2006; Ruiz et al., 2004; Baker et al., 2002; Leo \& Philippe, 2002; Van Kenhove et al., 1999; Dellaert et al., 1998; Bearden, 1977; Bellenger, 1977).

$\mathrm{H}_{13}$ : The retail tenant mix $\left(\xi_{3}\right)$ positively affects attractiveness $\left(\eta_{1}\right)$ an urban retail agglomeration.

$\mathrm{H}_{14} / \mathrm{H}_{15} / \mathrm{H}_{16}$ : The merchandise value $\left(\xi_{4}\right)$, product range $\left(\xi_{5}\right)$ and sales personnel $\left(\xi_{6}\right)$ of the retail tenant positively affects the attractiveness $\left(\eta_{1}\right)$ of an urban retail agglomeration.

The offer of an urban place also contains non retail service businesses. These include bars and restaurants $\left(x_{71}\right)$, and service stores, e.g. bank outlets, hairdresser, repair service providers, butcher, bakeries or cinemas $\left(x_{72}\right)$ (e.g., Wakefield \& Baker, 1998). The non retail tenant mix enriches the retail offer by broadening the opportunity to conduct multi-purpose shopping trips with respect to service and food consumption, and entertainment. It can be seen as a distinct characteristic of urban places for groups who do not use the urban place exclusively for shopping, e.g. residents, tourists, visitors and company of shoppers.

According to Teller (2008) and Wakefield and Baker (1998) we therefore propose that:

$\mathrm{H}_{17}$ : The non retail tenant mix $\left(\xi_{7}\right)$ affects the attractiveness $\left(\eta_{1}\right)$ of an urban retail agglomeration.

Atmosphere of urban retail agglomerations

Another group of attributes are the set of cues that a place user senses. These include visual, olfactory, tactile and auditory stimuli. In terms of urban places attributes such as atmospheric stimuli account for odour $\left(x_{81}\right)$, air $\left(x_{82}\right)$, temperature $\left(x_{83}\right)$, light $\left(x_{84}\right)$, cleanliness $\left(x_{85}\right)$, 
architecture $\left(x_{86}\right)$, mood $\left(x_{87}\right)$ and the atmosphere as a whole $\left(x_{88}\right)$ (e.g., Ruiz et al., 2004; Baker et al., 2002; McGoldrick \& Pieros, 1998). These stimuli are relatively difficult to control due to the open air character together with the relative absence of a powerful management structure for urban retail agglomerations (Teller \& Elms, 2010). Nevertheless, the atmosphere and all its elements - e.g. historic architecture, fresh air, etc. - can be seen as a unique feature of urban retailing that can be used for competitive advantage (Hackett \& Foxall, 1994).

The crucial importance of atmospheric stimuli for an urban place results into the following hypothesis (Michon et al., 2005; Ruiz et al., 2004; Hoffman \& Turley, 2002; McGoldrick \& Pieros, 1998; Donovan et al., 1994):

$\mathrm{H}_{18}$ : The atmosphere $\left(\xi_{8}\right)$ positively affects the attractiveness $\left(\eta_{1}\right)$ of an urban retail agglomeration.

\section{(Infra-)Structure of urban retail agglomerations}

The last set of attributes contains, firstly, the internal accessibility in terms of the unproblematic $\left(x_{91}\right)$, quick and safe manoeuvrability $\left(x_{92}\right)$, the ease of orientation $\left(x_{93}\right)$ within the agglomeration and the clear arrangement of stores $\left(x_{94}\right)$ (e.g., Baker et al., 2002; Van Kenhove et al., 1999; Brown, 1988). Furthermore, infrastructural services like the provision of public toilets $\left(x_{101}\right)$, cash dispensers $\left(x_{102}\right)$ and recreational areas $\left(x_{103}\right)$ can facilitate the shopping process for customers (e.g., Baker et al., 2002; Tang et al., 2001). For all these attributes, the evolving character of urban agglomerations can be problematic. As a result, they are relatively difficult to manage. Nevertheless, all this contributes to the unique character of urban retail agglomerations and, as such, as with the tenant mix and the atmosphere this provides a source for differentiation compared to other urban places and unified retail agglomerations that are created. 
By following the notions of Teller et al. (2008), Baker et al. (2002), Van Kenhove et al. (1999) or Bellenger (1977) we hypothesise that:

$\mathrm{H}_{19} / \mathrm{H}_{110}$ : The manoeuvrability/orientation $\left(\xi_{9}\right)$ within and infrastructural facilities $\left(\xi_{10}\right)$ positively affect the attractiveness $\left(\eta_{1}\right)$ of an urban retail agglomeration.

\section{Interrelated attributes of urban retail agglomerations}

Teller and Reutterer (2008) emphasise that agglomeration attributes are interrelated and cannot be seen as isolated. Consequently, attractiveness can also be influenced indirectly and thus additionally by certain attributes. The attribute retail tenant mix as consequence of the application of the 'macro marketing mix' on an agglomeration level is influenced by attributes resulting out of the application of the 'micro marketing mix' on a store level (Hart, 2009). According to the store patronage literature such (store) attributes are accessibility including manoeuvrability/orientation, parking conditions - merchandise value, the product range and sales personnel (e.g., Reutterer \& Teller, 2009; Severin et al., 2001). Furthermore, the non retail element can be seen as a complement and a positive driver of the perception of the retail element of an agglomeration (Dennis et al., 2005; Whyatt, 2004; Wakefield and Baker, 1998). We therefore can set up the following hypotheses:

$\mathrm{H}_{31} / \mathrm{H}_{32} / \mathrm{H}_{39}$ : The accessibility $\left(\xi_{1}\right)$, the parking conditions $\left(\xi_{2}\right)$ and the manoeuvrability/orientation $\left(\xi_{9}\right)$ positively affect the perception of retail tenant mix $\left(\xi_{3}\right)$ of an urban retail agglomeration.

$\mathrm{H}_{34} / \mathrm{H}_{35} / \mathrm{H}_{36}$ : The merchandise value $\left(\xi_{4}\right)$, product range $\left(\xi_{5}\right)$ and sales personnel $\left(\xi_{6}\right)$ positively affects perception of retail tenant mix $\left(\xi_{3}\right)$.

$\mathrm{H}_{37}$ : The non retail tenant mix $\left(\xi_{7}\right)$ of an urban place positively affects the retail tenant mix $\left(\xi_{3}\right)$

It is worth mentioning that within the 'micro marketing mix' two attributes show a close relationship since they both describe the characteristics of product choice on a store level, i.e. 
the merchandise value and the product range (e.g. Severin et al., 2001; Bearden, 1977). We therefore propose that

$\mathrm{H}_{54}$ : The merchandise value $\left(\xi_{4}\right)$ positively affects the perception of the product range $\left(\xi_{5}\right)$ of urban retail agglomerations.

Finally, some attributes of urban retail agglomerations can be seen as atmospheric cues and thus contributing to the overall atmosphere (Teller \& Reutterer, 2008). All attributes operationalising the retail and non retail offer and the (infra-) structure of urban retail agglomerations can be seen as or sending out visual, tactile, auditory but also olfactory stimuli (Michon et al., 2005; McGoldrick \& Pieros, 1998; Donovan et. al., 1994). We consequently set up the following two sets of hypotheses:

$\mathrm{H}_{83} / \mathrm{H}_{87} / \mathrm{H}_{85} / \mathrm{H}_{86}$ : The retail $\left(\xi_{3}\right)$ and non retail tenant mix $\left(\xi_{7}\right)$, product range $\left(\xi_{5}\right)$ and sales personnel $\left(\xi_{6}\right)$ positively affects the atmosphere $\left(\xi_{8}\right)$ of an urban retail agglomeration.

$\mathrm{H}_{89} / \mathrm{H}_{810}$ : The manoeuvrability/orientation $\left(\xi_{9}\right)$ within and infrastructural facilities $\left(\xi_{10}\right)$ positively affect perception of atmosphere $\left(\xi_{8}\right)$ of an urban retail agglomeration.

The proposed hypotheses $\left(\mathrm{H}_{\mathrm{n}}\right)$ are depicted in Figure 1 in terms of effects which are denoted with the Greek letter gamma $\left(\gamma_{\mathrm{nm}}\right)$. All factors, i.e. attributes, within this model are of a latent character $\left(x_{1}-x_{10}\right)$ and are operationalised by two or more indicators $\left(x_{\mathrm{m}}\right)$. As discussed in the previous section attractiveness is a (second order) construct $\left(\eta_{1}\right)$ operationalised by another three latent factors $\left(\eta_{11}, \eta_{12}\right.$ and $\left.\eta_{13}\right)$ each having three items standing behind them $\left(y_{\mathrm{n}}\right)$. The single items and pre-tested scales where taken from Teller et al. (2008) and are shown in the appendix.

\section{INSERT FIGURE 1 ABOUT HERE}




\section{Empirical Study}

\section{Methodology}

To test the proposed hypotheses in our model, an empirical study focussing an urban retail agglomeration of a capital city of a political district with more than 25,000 inhabitants within a catchment of 55,000 was conducted. The choice of the empirical setting was guided by its precise geographic boundaries. Although the town centre contains the largest and most important retail agglomeration, it has lost some of its importance to a strip centre on its edge together with a regional mall on the periphery of the town boundaries. Not only does the town centre lack large scale retailers, but it has also suffered from the loss of attractive tenants compared to the other two created retail agglomerations. Furthermore, the town centre competes with the strip centre for fashion and sports products, and with the regional mall for fashion, electronics and IT products. Although the town centre retailers try to work together through joint communication activities, no professional urban place marketing management or concept exists. Apart from two small fashion-dominated department stores $(1,500-2,500$

$\mathrm{m}^{2}$ ), the most common store formats are independently owned small/medium-sized specialty stores $\left(200-800 \mathrm{~m}^{2}\right)$.

Across the retail portfolios of the three agglomerations, Pan-European category killers such as IKEA for furniture, Mediamarkt/Saturn for electronics and Hennes \& Mauritz, Zara or Mango for fashion are missing. These retailers can be found in the two considerably bigger provincial capital cities, which both have populations of around 200,000 and each are within an hour's drive. Retail agglomerations near or in these two provincial capitals can be considered as being the supra-regional competitors for the town centre under investigation.

In order to test our model a survey approach was adopted whereby actual shoppers were interviewed immediately after they had entered the town centre (Teller \& Reutterer, 2008). The basic idea standing behind this survey approach was to confront customers with questions 
in the context of a real shopping situation and within a real shopping environment (Bloch et al., 1994). As a consequence we focus on those informants having a high degree of knowledge about the retail sites and their shopping behaviour (Campbell, 1955). Finally, this approach enabled us to collect data on the actual shopping situation operationalised in our model, i.e. retention proneness (Van Kenhove et al., 1999). According to the notions of Sudman (1980) sample points were determined at four different entrance areas. At these points professional interviewers were able to intercept customers entering the agglomeration at the beginning of their visit to the town centre. Those individuals who did not intend to buy or consume any kind of product or service during their visit at all or had visited the town centre for the first time were excluded from participating. Every fifteen minutes customers passing by a defined sampling mark were invited for interview. The number of individuals selected over the course of the day was adapted to the volume of customers entering the town centre at each sampling point. This was pre-tested before the main study had started. Over a period of three weeks a random sample of 486 was collected representing the clientele from both a spatial (sample selection points) and a temporal point of view (sample selection times). By applying a standardised questionnaire, which was administered by the interviewer, allowed the respondents to reflect upon and then record their shopping behaviour and perceptions, together with evaluations, with respect to the town centre. The research instrument (i.e. questions and interviewer instructions) was available in English (see appendix) and the language spoken in the retail area whereas the linguistic equivalence was ensured by applying the back translation procedure (Behling \& Law, 2000). The interviews were conducted exclusively in the local (non-English) language.

\section{Sample Description}

The sample does not reflect the demographic structure of the population of the town and surrounding area at an individual level; it does at a household level (household size and 
income; see Table 1). A major driver for this is the role split within households when it comes to shopping. Relative to the general population in the catchment area, the town centre clientele can be characterised by being comparable young, female, having low individual income and low level of educational attainment.

\section{INSERT TABLE 1 ABOUT HERE}

The variables operationalising the (average) shopping behaviour on site show both a strong "agglomeration effect" (Teller et al., 2008) generated by the stores within this urban retail cluster and the capability of our respondents to serve as competent informants for our questions on this retail agglomeration. This is particularly the case for the shopping frequency, the retail related spending and the retention time. In terms of the actual visiting purpose at the beginning of their trip more than four out of five of the respondents intended to buy products either for themselves or for someone else. Only a small number of respondents stated that they came to the town centre with another reason in mind, however this did not mean that they did not purchase anything by the end of their shopping trip. Finally, it has to be mentioned that our respondents show a high out-shopping propensity. $71.5 \%$ stated that they could think of doing a similar shopping trip elsewhere. Out of these $77.5 \%$ stated that they preferred either of the two provincial capital cities as their preferred shopping destination. This suggests that the inter-regional competition between the town centre and other agglomerations in higher order urban areas is considerable.

\section{Results}

\section{Local and Global Model Fit}

In order to measure the effects between the latent (reflective) constructs, i.e. factors, proposed in the model, a structural equation modelling approach was used - e.g., Hair et al. (2009) or Kaplan (2000). The measurement validity of the exogenous $\left(\xi_{1}-\xi_{10}\right)$ and endogenous 
measurement model $\left(\eta_{1} ; \eta_{11}-\eta_{13}\right)$ was tested according to Churchill (1979) and Bagozzi et al. (1991) (see appendix). Cronbach Alpha $(\alpha)$ coefficients were calculated for each factor and confirmatory analyses (CFA) for each measurement model. All factor loadings - including those of the second order construct's prove to be significant $(p<.01)$. By interpreting the local fit measures, the internal consistency $(\alpha)$ can be considered to be satisfactory for all factors (> 0.7). The composite reliability also meets the requirement to be above 0.6 ( $\rho$, Fornell \& Larcker, 1981) with the average variances extracted (AVE) in an acceptable range around 0.5 (Bagozzi \& Yi, 1988). With regard to the constructs discriminant validity, it can be said that the AVE is larger than the highest squared intercorrelation with every other factor in the measurement models (Fornell-Larcker-Ratio (FLR) $<1$; Fornell \& Larcker, 1981). It should be mentioned that the intercorrelation between the retail tenant mix $\left(\xi_{3}\right)$, merchandise value $\left(\xi_{4}\right)$ and product range $\left(\xi_{5}\right)$ is considerably high but the FLR for each of the constructs is still under the recommended cut-off value. Based on these results, the local fit of the measurement models was satisfactory. Finally, the absolute, incremental and parsimonious fit of our model meets the recommended values (Hu \& Bentler, 1998, 1999; Anderson \& Gerbing, 1988; see Table 2). From this, the empirical data of all the samples fits the proposed baseline model to a satisfactory degree.

\section{Structural Effects}

As shown in Table 2, the size of direct, indirect and total effects can be seen from the (standardised path) coefficients. A coefficient below 0.1 indicates a low or marginal effect, values around 0.3 a medium effect and above 0.5 a considerable or substantial effect (Cohen, 1988). Overall, eleven direct effects and six indirect effects and consequently fourteen total effects proposed in the model turned out to be significant (Critical Ratio>1.96; $p<.05$ ). 
By first looking at the proposed effects between the agglomeration attributes the most substantial impact can be identified between the merchandise value and the product range $\left(\gamma_{54}\right)$. This clearly confirms hypothesis $\mathrm{H}_{54}$. The retail tenant mix is considerably directly affected by the product range $\left(\gamma_{35}\right)$ and marginally impacted by non retail tenant mix $\left(\gamma_{37}\right)$ and parking conditions $\left(\gamma_{32}\right)$. By taking into account the mediating role of the factor product range the factor merchandise value has a significant indirect and consequently medium size total effect on the tenant mix. As a consequence hypotheses $\mathrm{H}_{32}, \mathrm{H}_{34}, \mathrm{H}_{35}$ and $\mathrm{H}_{37}$ can be accepted. Regarding the atmosphere in the urban retail agglomeration the manoeuvrability and orientation $\left(\gamma_{89}\right)$ and the sales personnel $\left(\gamma_{86}\right)$ show a medium (direct and total) impact - the two tenant mix related factors $\left(\gamma_{83} ; \gamma_{87}\right)$ at least marginal effects. These results lead to the confirmation of the hypotheses $\mathrm{H}_{83}, \mathrm{H}_{86}, \mathrm{H}_{87}$ and $\mathrm{H}_{89}$. Due the lack of significant direct or total effects all the other hypotheses - $\mathrm{H}_{31}, \mathrm{H}_{36}, \mathrm{H}_{39}, \mathrm{H}_{85}$ and $\mathrm{H}_{810}$ - proposing impacts between attributes are rejected.

INSERT TABLE 2 ABOUT HERE

Based on the identified significant interdependencies and by finally referring to the research question three factors prove to be of determinant direct, indirect and total importance for the attractiveness of the urban retail agglomeration under investigation, i.e. the retail tenant mix $\left(\gamma_{13}\right)$, the merchandise value $\left(\gamma_{14}\right)$ and the atmosphere $\left(\gamma_{18}\right)$. We therefore can accept hypotheses $\mathrm{H}_{13}, \mathrm{H}_{14}$ and $\mathrm{H}_{18}$. Considering the significant mediated (indirect) effects and interpreting the total effects it can be shown that additionally the product range and the sales personnel - both mediated by the retail tenant mix and the atmosphere - are of significant relevance for the attractiveness and therefore can be denoted as antecedents. This result leads to the acceptance of $\mathrm{H}_{15}$ and $\mathrm{H}_{16}$. The value of the total effects show that the merchandise value followed by the retail tenant mix have a substantial impact whereas the product range 
and the atmosphere affect attractiveness to a medium degree. The sales personnel is of marginal significant importance.

All the location related factors (accessibility, parking conditions), the non retail tenant mix and infrastructural facilities show no significant direct or indirect impact on the endogenous factor. Nevertheless, the indirect effect of manoeuvrability and orientation $\left(\gamma_{89} * \gamma_{18}\right)$ turned out to be significant whereas the total effect is not. Consequently these insignificant factors cannot be seen as direct or indirect antecedents of attractiveness - therefore we reject hypotheses $\mathrm{H}_{11}, \mathrm{H}_{12}, \mathrm{H}_{17}, \mathrm{H}_{19}$ and $\mathrm{H}_{110}$.

Finally it has to be mentioned that the squared multiple correlations of the second order construct attractiveness (exogenous factor, $\eta_{1}$ ) shows that a considerable share of variance is explained by the exogenous factors $\left(\xi_{1}-\xi_{10} ; r^{2}=.890\right)$.

\section{Discussion}

The Crucial Role of Retailing for Urban Place Attractiveness: The results confirm the crucial importance of the retail tenant mix and the atmosphere for retail agglomeration formats of any kind (e.g., Hart, 2009; Teller \& Reutterer, 2008; Michon et al., 2005; Ruiz et al., 2004; Leo \& Philippe, 2002; McGoldrick \& Pieros, 1998; Hackett \& Foxall, 1994). This can be further supported since the value of merchandising being a core responsibility of retailers is of direct and indirect importance for the attractiveness of the place (Baker et al., 2002). This is underlined by the result that this factor has an influence on the perception of the product range offered by the retail tenants which in turn - together with the perception of the sales personnel - affects the overall atmosphere. It can be confirmed that retailers are a major attractor for an urban place (product) (Short \& Kim, 1998) in that they actively and substantially change the attractiveness of a place (Warnaby et al., 2006).

The supportive and guiding role of place marketing for urban retailing: So far, literature has not differentiated between core and auxiliary functions of place marketing with respect to 
how this influences the patronage behaviour of place user groups (Teller, 2008). Our results suggest such a split of responsibilities exists between retailers and place managers/marketers. Regarding the identified antecedents of retail related place attractiveness, only the atmosphere can be directly influenced by place marketing jointly coordinated with retailers and other tenants. Nevertheless, place (marketing) manager can focus on changing parking conditions or the manoeuvrability and the orientation of place users having an effect on the identified antecedents (Tang et al., 2001; Van Kenhove et al., 1999; Van der Waerden et al., 1998). Most importantly, the acquisition and the retention of attractive retail tenants should be a core task of place management and marketing. This is also true for non retail tenants since they affect the perception of the retail parade in and the atmosphere of an urban place (Whyatt, 2004; Wakefield \& Baker, 1998).

The lower importance of structural disadvantages: Retailing in urban places suffers from not being embedded within purpose built shopping environments (Teller \& Elms, 2010). Compared to created retail agglomerations, an evolved retail agglomeration can be more challenging to manage efficiently (Teller, 2008). In that respect, the accessibility and infrastructural facilities of urban retail agglomerations proved to be inferior compared to e.g. peripheral and centrally managed shopping malls. The results showed that neither of these two factors impacted upon the attractiveness of the urban place. This contradicts the notions from e.g. Leo and Philippe (2002), Reimers and Clulow (2004; 2009) or Arentze and Timmermans (2001). Thus, it can be concluded that the urban retail agglomeration under investigation is attractive or can be made more attractive to place users regardless of accessibility and the shopping infrastructure. This is consistent with the findings of research that has focussed on different retail agglomeration formats (e.g. Teller \& Reutterer, 2008; Teller, 2008). However, this must not be interpreted that these two attributes are unimportant, rather that they were considered as an essential pre-condition and, thus, were not of value as a 
differentiating tool for place marketers in this particular town. Nevertheless it is obvious that a dramatic (non linear) change in structural attributes - e.g. introducing congestion charges, additional parking charges, imposing additional restrictions on the access - can result in such factors being extremely salient to urban retail agglomeration patronage decisions and thus a concern for place marketers.

\section{Implications for place marketing and marketers}

Van den Berg and Braun (1999) observ that urban locations tended to 'invent' their marketing strategies, the research suggests that the urban place - including retail agglomerations - can be, and needs to be, grounded in evidence. Instead of promoting the retail related component of an urban product through marketing strategies that lack reference to the needs of place users in particular actual shoppers, competitiveness can be better developed through a more targeted product proposition. An understanding of the nature of the underlying attractiveness antecedents can allow place marketers to capitalise on the urban product's characteristics that are most significant and, consequently, most valued by the place user group of consumers actually patronising an urban place. Systematically applying this "place formation" process (Aiesha, 2006), rather than assuming that the urban product should consist of particular characteristics that may not necessarily be valued, should then maximise the likelihood that place marketers efforts coalesce with place users needs. Embedding these place marketing activities requires that a more attuned focus on the market is stressed with this tallying with the need to avoid prescriptive sales-driven approaches.

As noted by Warnaby et al. (2002), the commodification process is integral to place marketing. In packaging a relevant 'bundle' of attributes, the relative significance within each urban retail agglomeration needs to be recognised and then harnessed. Consequently, place marketers should stress the attractiveness that has greatest significance for place users in 
urban places. Several benefits could accrue. Firstly, a selective focus should avoid the tendency for place marketers to produce homogenised products whereby a relatively standardised repertoire, in terms of what is constituted within the urban place, is presented to place users (Warnaby \& Medway, 2004). In contrast, a nuanced approach can emphasise the more pivotal, as opposed to the less significant, characteristics as a differentiator. The urban place can then be honed to, rather than imposed upon, place users.

Alongside the most significant characteristics, there are others - in particular accessibility which lack any significance. Consequently, urban places need to ensure that these do not detract from characteristics that build value and utility for place users more decisively. In turn, though, disaggregating urban retail agglomeration characteristics, on the basis of relative significance, enables 'place formation' to be a determinant of where place marketers should direct resources. In the case of the urban evolved retail agglomeration under investigation, the retail tenant mix and factors associated with atmosphere deserve most of management attention (Teller \& Elms, 2010).

\section{Limitations and directions for further research}

In interpreting the empirical evidence, several limitations need to be taken into account. The choice of the urban retail agglomeration within a spatially bounded area was influenced by Teller (2008), who indicated that evolved retail agglomeration formats, in general, and regional agglomerations, in particular, have not been the focus of research attention to a satisfactory degree. Nevertheless, the empirical evidence can only be applied to similar urban place settings and agglomerations with the result being that where retail provision within a town centre includes a powerful (inner city) shopping centre other results could be obtained. By heeding the call from Evanschitzky et al. (2007) for critical replication studies in marketing, there is a rationale for applying this model empirically in other spatial contexts. Although a strength of this paper, the deliberate choice of actual shoppers as informants 
carries the limitation that other consumer groups such as non existing customers (past and future) or customers who visit the retail agglomeration under investigation only occasionally are not covered in the sample. Whilst we can trust our data in terms of a high internal validity the findings presented in this paper are inevitably biased towards existing customers who display a high(er) shopping frequency. In addition, the specific shopping or visiting situations around which the interviews occurred limits the research's transferability beyond that of this study. By applying the ideas of Van Kenhove et al. (1999) the shopping situation can have an impact on the perception of attributes and the evaluation of attractiveness (Teller \& Reutterer, 2008). A survey approach, which involves home interviews with consumers, may consequently lead to different results. Furthermore, the focus was only on retail and retailrelated characteristics of each $\mathrm{AF}$, and, as such, other potentially relevant purposes were not researched. In short, the research only reflected the perceptions of one place user group - the retail customers (Ashworth \& Voogd, 1994).

Future research should attempt to extend our conceptual model and include behavioural measures as endogenous variables such as the share of spending, the share of time and the share of visit consumers dedicate to a particular place compared to others. These variables could then be interpreted as behavioural measures of attractiveness.

As an initial step in investigating place users from a place marketing perspective, these results need to be extended towards specific place user groups distinguished by demographic and psychographic characteristics such as place of residence, purpose and frequency of usage together with attitude towards the place in order to know more about their needs, wants, perceptions and behaviour. 


\section{References}

Aiesha, R. (2006). Place Marketing and the Planning Process. In Proceedings of the CIRM Conference - Destinations and Locations: Exploring the Multiple Identities of Place (pp. 12). Manchester: Manchester Metropolitan University.

Alzubaidi, H., \& Vignali, C. (1997). Town Centre Versus Out-of-town Shopping: A Consumer Perspective. International Journal of Retail and Distribution Management, 25, 7889.

Anderson, J.C., \& Gerbing, D.W. (1988). Structural Equation Modelling in Practice: A Review and Recommended Two-step Approach. Psychological Bulletin, 103, 411-423.

Anselmsson, J. (2006). Sources of Customer Satisfaction with Shopping Malls: A Comparative Study of Different Customer Segments. International Review of Retail, Distribution and Consumer Research, 16, 115-138.

Arentze, T. A., \& Timmermans, H. J. P. (2001). Deriving Performance Indicators From Models of Multipurpose Shopping Behaviour. Journal of Retailing and Consumer Services, 8, 325-334.

Ashworth, G.J., \& Voogd, H. (1994). Marketing and Place Promotion. In J.R. Gold, \& Ward, S.V. (Eds.), Place Promotion: the Use of Publicity and Marketing to Sell Towns and Regions (pp. 39-52), Chichester: John Wiley.

Bagozzi, R. P., \& Yi, Y. (1988). On the Evaluation of Structural Equation Models. Journal of the Academy of Marketing Science, 16, 74-94.

Bagozzi, R.P., Yi, Y., \& Phillips, L.W. (1991). Assessing Construct Validity in Organizational Research. Administrative Science Quarterly, 36, 421-458.

Baker, J., Parasuraman, A., Grewal, D., \& Voss, G. B. (2002). The Influence of Multiple Store Environment Cues on Perceived Merchandise Value and Patronage Intentions. Journal of Marketing, 66, 120-141. 
Baker, R. G. V. (1996). Multi-purpose Shopping Behaviour at Planned Suburban Shopping Centres: A Space-Time Analysis. Environment and Planning A, 28, 611-630.

Bearden, W. O. (1977). Determinant Attributes of Store Patronage - Downtown Versus Outlying Shopping Centers. Journal of Retailing, 53, 15-22.

Behling, O., \& Law, K.S. (2000). Translating Questionnaires and Other Research Instruments: Problems and Solutions, Thousand Oaks/CA: Sage.

Bellenger, D. N. (1977). Shopping Center Patronage Motives. Journal of Retailing, 53, 29-38.

Bloch, P. H., Ridgway, N. M., \& Dawson, S. A. (1994). The Shopping Mall as Consumer Habitat. Journal of Retailing, 70, 23-42.

Brown, S. (1988). Information Seeking, External Search and Shopping" Behavior: Preliminary Evidence for a Planned Shopping Centre. Journal of Marketing Management, 4, 33-49.

Campbell, D. T. (1955). The Informant in Quantitative Research. The American Journal of Sociology, 60, 339-342.

Churchill, G. A. (1979). A Paradigm for Developing Better Measures of Marketing Constructs. Journal of Marketing Research, 16, 64-73.

Cohen, J. (1988). Statistical Power Analysis for the Behavioral Sciences, New York: Academic Press.

Dellaert, B. G. C., Arentze, T. A., Bierlaire, M., Borgers A. W. J., \& Timmermans, H. J. P. (1998). Investigating Consumers' Tendency to Combine Multiple Shopping Purposes and Destinations. Journal of Marketing Research, 35, 177-188.

Dennis, C., Marsland, D., \& Newman, A. (2005). Objects Of Desire: Consumer Behaviour In Shopping Centre Choices, Hampshire/New York: Palgrave MacMillan.

Donovan, R. J., Rossiter, J. R., Marcoolyn, G., \& Nesdale, A. (1994). Store Atmosphere and Purchasing Behaviour. Journal of Retailing, 70, 283-294. 
Eastlick, M. A., \& Feinberg, R. A. (1999). Shopping Motives for Mail Catalog Shopping. Journal of Business Research, 45, 281-290.

Evanschitzky, H., Baumgarth, C., Hubbard, R., \& Armstrong, J. S. (2007). Replication Research's Disturbing Trend. Journal of Business Research, 60, 411-415.

Finn, A., \& Louviere, J. J. (1996). Shopping Center Image, Consideration, and Choice: Anchor Store Contribution. Journal of Business Research, 35, 241-251.

Fornell, C., \& Larcker, D. F. (1981). Evaluating Structural Equation Models with Unobservable Variables and Measurement Error. Journal of Marketing Research, 18, 39-40.

Gower, R. (2008). People-Managed Places. Journal of Place Management and Development, $1,315-321$

Hackett, P. M. W., \& Foxall, G. R. (1994). A Factor Analytic Study of Consumers' Location Specific Values: A Traditional High Street and a Modern Shopping Mall. Journal of Marketing Management, 10, 163-178.

Hair, J. F., Black, W. C., Babin, B. J., \& Anderson, R. E. (2009). Multivariate Data Analysis, Upper Saddle River, New Jersey: Prentice Hall.

Hart, C. (2009). The Role of the Assortment in Retail Image. In J. R. Evans (Eds.), Proceedings of AMS/ACRA 2009 Fall Triennial Retailing Conference: Strategic Challenges and Opportunities in Uncertain Times, Vol. XII (pp. 115-121). Hempstead, NY: Academy of Marketing Science.

Hoffman, D. K., \& Turley, L. W. (2002). Atmospherics, Service Encounters and Consumer Decision Making: An Integrative Perspective. Journal of Marketing Theory and Practice, 10, $33-48$.

Hospers, G-J. (2006). Borders, Bridges and Branding: The Transformation of the Oresund Region into an Imagined Space. European Planning Studies, 14, 1015-1033. 
Howard, E. (1997). The Management of Shopping Centres: Conflict or Collaboration?. International Review of Retail, Distribution and Consumer Research, 7, 263-285.

Hu, L., \& Bentler, P. M. (1998). Fit Indices in Covariance Structure Modelling: Sensitivity to Underparameterized Model Misspecification. Psychological Methods, 3, 425-453.

Hu, L., \& Bentler, P. M. (1999). Cutoff Criteria for Fit Indexes in Covariance Structure Analysis: Conventional Criteria Versus New Alternatives. Structural Equation Modelling, 6, $1-55$.

Insch, A., \& Florek, M. (2008). A Great Place to Live, Work and Play: Conceptualising Place Satisfaction in the Case of a City's Residents. Journal of Place Management and Development, 1, 138-149.

Kaplan, D. (2000). Structural Equation Modeling. Foundation and Extensions, Thousand Oak (CA): Sage Publications.

Leo, P. Y., \& Philippe, J. (2002). Retail Centres: Location and Consumer's Satisfaction. Service Industries Journal, 22, 122-146.

Madsen, H. (1992). Place-Marketing in Liverpool: A Review. International Journal of Urban and Regional Research, 16, 633-640.

McGoldrick, P. J., \& Pieros, C. P. (1998). Atmospheres, Pleasure and Arousal: The Influence Of Response Moderators. Journal of Marketing Management, 14, 173-197.

Mehrabian, A., \& Russel, J. A. (1974). An Approach to Environmental Psychology, Cambridge (MA): MIT-Press.

Michon, R., Chebat, J. C., \& Turley, L. W. (2005). Mall Atmospherics: The Interaction Effects of the Mall Environment on Shopping Behaviour. Journal of Business Research, 58, $576-583$

Oppewal, H., \& Holyoake, B. (2004). Bundling and Retail Agglomeration Effects on Shopping Behaviour. Journal of Retailing and Consumer Services, 11, 61-74. 
Prendergast, G., Marr, N., \& Jaratt, B. (1998). Retailers' Views of Shopping Centres: A Comparison of Tenants and Non-Tenants. International Journal of Retail and Distribution Management, 26, 162-171.

Reichheld, F. F. (2001). The Loyalty Effect: The Hidden Force Behind Growth, Profits, and Lasting Value: The Hidden Force Behind Growth, Profits and Lasting Value, New York: Mcgraw-Hill.

Reimers, V., \& Clulow, V. (2004). Retail Concentration: A Comparison of Spatial Convenience in Shopping Strips and Shopping Centres. Journal of Retailing and Consumer Services, 11, 207-221.

Reimers, V., \& Clulow, V. (2009). Retail Centres: it s time to make them convenient. International Journal of Retail and Distribution Management, 37, 541-562.

Reutterer, T., \& Teller, C. (2009). Store Format Choice and Shopping Trip Types. International Journal of Retail and Distribution Management, 37, 695-710.

Ruiz, J. P., Chebat, J. C., \& Hansen, P. (2004). Another Trip to the Mall: A Segmentation Study of Customers Based on their Activities. Journal of Retailing and Consumer Services, $11,333-350$.

Schnedlitz, P., \& Teller, C. (2008). Das Einkaufszentrum als Agglomerationsklasse begriffliche Diskussion und empirische Evaluierung von Agglomerationseffekten [Shopping centers as a distinct agglomeration format - conceptual discussion and empirical evaluation of agglomeration effects]. In M. Gruber (Ed), Agglomerationseffekte und Bestandverhaeltnisse in Einkaufszentren [Agglomeration effects and leasing agreements in shopping centers] (pp. 1-52), Vienna: Manz.

Severin, V., Louviere, J. J., \& Finn, A. (2001). The Stability of Retail Shopping Choices Over Time and Across Countries. Journal of Retailing, 77, 185-202. 
Shaw, G., \& Williams, A. (1992). Tourism, Development and the Environment: The Eternal Triangle, in: C.P. Cooper, \& Lockwood, A. (Eds.), Progress in Tourism, Recreation and Hospitality Management, Vol. 4 (pp. 47-59), London: Belhaven Press.

Short, J. R., \& Kim, Y-H. (1998). Urban Crises/Urban Representations: Selling the City in Difficult Times. In T. Hall, \& Hubbard, P. (Eds.), The Entrepreneurial City: Geographies of Politics, Regimes and Representations (pp.55-75), Chichester: John Wiley.

Skinner, H. (2008). The Emergence and Development of Place Marketing's Confused Identity. Journal of Marketing Management, 24, 915-928.

Sudman, S. (1980). Improving the Quality of Shopping Center Sampling. Journal of Marketing Research, 17, 423-431.

Tang, C. S., Bell, D. R., \& Ho, T.-H. (2001). Store Choice and Shopping Behavior: How Price Format Works. California Management Review, 43, 56-74.

Teller, C. (2008). Shopping Streets Versus Shopping Malls - Determinants of Agglomeration Format Attractiveness from the Consumers' Point of View. International Review of Retail, Distribution and Consumer Research, 18, 381-403.

Teller C., Kotzab, H., \& Grant, D. B. (2006). The Consumer Direct Services Revolution in Grocery Retailing: an exploratory investigation. Managing Service Quality, 16, 78-96.

Teller, C., \& Reutterer, T. (2008). The Evolving Concept of Retail Attractiveness: What Makes Retail Agglomerations Attractive when Customers Shop at Them?" Journal of Retailing and Consumer Services, 15, 127-143.

Teller, C., Reutterer, T., \& Schnedlitz, P. (2008). Hedonic and Utilitarian Shopper Types in Evolved and Created Retail Agglomerations. International Review of Retail, Distribution and Consumer Research, 18, 283-309.

Teller C., \& Elms, J. R. (2010). Managing the Attractiveness of Evolved and Created Retail Agglomeration Formats. Marketing Intelligence \& Planning, 28, 25-45. 
Van den Berg, L., \& Braun, E. (1999). Urban Competitiveness, Marketing and the Need for Organising Capacity. Urban Studies, 36, 987-999.

Van der Waerden, P., Borgers, A., \& Timmermans, H. (1998). The Impact of the Parking Situation in Shopping Centres on Store Choice Behaviour. GeoJournal, 45, 309-315.

Van Kenhove, P., de Wulf, K., \& van Waterschoot, W. (1999). The Impact of Task Definition on Store-Attribute Saliences and Store Choice. Journal of Retailing, 75, 125-137.

Wakefield, K. L., \& Baker, J. (1998). Excitement at the Mall: Determinants and Effects on Shopping Response. Journal of Retailing, 74, 515-539.

Warnaby, G., \& Medway, D. (2004). The Role of Place Marketing as a Competitive Response by Town Centres to Out-of-Town Retail Developments. International Review of Retail, Distribution and Consumer Research, 14, 457-477.

Warnaby, G., Bennison, D., \& Davies, B.J. (2005). Retailing and the Marketing of Urban Places: A UK Perspective. International Review of Retail, Distribution and Consumer Research, 15, 191-215.

Warnaby, G., Bennison, D., \& Medway, D. (2006). The Role of SME Retailers in Locational Differentiation. In Proceedings of the CIRM Conference - Destinations and Locations: Exploring the Multiple Identities of Place (pp. 167-173), Manchester: Manchester Metropolitan University.

Warnaby, G., Bennison, D., Davies, B.J., \& Hughes, H. (2002). Marketing UK Towns and Cities as Shopping Destinations. Journal of Marketing Management, 18, 877-904.

Warnaby, G., \& Davies, B. J. (1997). Commentary: Cities as Service Factories? Using the Servuction System for Marketing Cities. International Journal of Retail and Distribution Management, 25, 204-210.

Whyatt, G. (2004). Town Centre Management: How Theory Informs a Strategic Approach. International Journal of Retail and Distribution Management, 32, 346-353. 
Appendix: Rating results and local fit measures

\begin{tabular}{|c|c|c|c|c|}
\hline \multicolumn{2}{|c|}{$\begin{array}{l}\text { (latent) Factor } \\
\text { Indicator }\end{array}$} & $\mu(\sigma)$ & $\rho / \alpha$ & AVE/FLR \\
\hline \multicolumn{5}{|c|}{ Accessibility $\left(\xi_{1}\right)$} \\
\hline$x_{11}$ & You can get easily get to the town centre. ${ }^{a}$ & $4.5(1.9)$ & \multirow{3}{*}{$.932 / .934$} & \multirow{3}{*}{$.826 / .130$} \\
\hline$x_{12}$ & You can get to the town centre quickly. ${ }^{\mathrm{a}}$ & $4.4(1.9)$ & & \\
\hline & You can get to the town centre without problems. ${ }^{\text {a }}$ & $4.6(1.8)$ & & \\
\hline \multicolumn{5}{|c|}{ Parking conditions $\left(\xi_{2}\right)$} \\
\hline$x_{21}$ & The town centre has always enough free parking lots. ${ }^{a}$ & $2.3(2)$ & \multirow{5}{*}{$.714 / .719$} & \multirow{5}{*}{$.466 / .489$} \\
\hline$x_{22}$ & The town centre offers different parking facilities sufficiently. ${ }^{a}$ & $3.3(1.9)$ & & \\
\hline$x_{23}$ & The town centre can be reached from the parking lots easily. ${ }^{\mathrm{a}^{\dagger}}$ & \multirow{3}{*}{$4.1(1.5)$} & & \\
\hline$x_{24}$ & The town centre can be reached from the parking lots safely. ${ }^{a \dagger}$ & & & \\
\hline$x_{26}$ & The town centre can be reached from the parking lots quickly. ${ }^{\mathrm{a} \dagger}$ & & & \\
\hline \multicolumn{5}{|c|}{ Retail tenant mix $\left(\xi_{3}\right)$} \\
\hline$x_{31}$ & The town centre has a broad range of retail stores. ${ }^{a}$ & $3.7(1.5)$ & \multirow{3}{*}{$.886 / .892$} & \multirow{3}{*}{$.736 / .823$} \\
\hline$x_{32}$ & The town centre has an attractive range of retail stores. ${ }^{a}$ & $3.5(1.5)$ & & \\
\hline$x_{33}$ & Many well-known retail stores are in the town centre. ${ }^{a}$ & $3.7(1.5)$ & & \\
\hline \multicolumn{5}{|c|}{ Merchandise value $\left(\xi_{4}\right)$} \\
\hline$x_{41}$ & The overall price level is low in the town centre. ${ }^{a}$ & $3.0(1.2)$ & \multirow{3}{*}{$.775 / .782$} & \multirow{3}{*}{$.550 / .891$} \\
\hline$x_{42}$ & You can find a lot of special offers in the town centre. ${ }^{a}$ & $3.6(1.4)$ & & \\
\hline$x_{43}$ & The price-quality ratio is good in the town centre. ${ }^{a}$ & $3.7(1.3)$ & & \\
\hline \multicolumn{5}{|c|}{ Product range $\left(\xi_{5}\right)$} \\
\hline$x_{51}$ & There are a wide choice of products in the town centre. ${ }^{\mathrm{a}}$ & $3.8(1.3)$ & \multirow{3}{*}{$.884 / .884$} & \multirow{3}{*}{$.717 / .683$} \\
\hline$x_{52}$ & There are a wide choice of products in each category in the town centre. ${ }^{a}$ & $3.7(1.4)$ & & \\
\hline$x_{53}$ & There are a wide choice of brands in the town centre. ${ }^{\text {a }}$ & $3.9(1.4)$ & & \\
\hline \multicolumn{5}{|c|}{ Sales personnel $\left(\xi_{6}\right)$} \\
\hline$x_{61}$ & Personnel are friendly in the town centre. ${ }^{\mathrm{a}}$ & $4.1(1.5)$ & \multirow{3}{*}{$.934 / .935$} & \multirow{3}{*}{$.827 / .337$} \\
\hline$x_{63}$ & Personnel are competent in the town centre. ${ }^{a}$ & $4.0(1.5)$ & & \\
\hline$x_{63}$ & Personnel are helpful in the town centre. ${ }^{a}$ & $4.2(1.5)$ & & \\
\hline \multicolumn{5}{|c|}{ Non retail tenant mix $\left(\xi_{7}\right)$} \\
\hline$x_{71}$ & The town centre has a broad range of bars and restaurants. ${ }^{a}$ & $4.0(1.6)$ & \multirow{2}{*}{$.645 / .649$} & $481 / 783$ \\
\hline$x_{72}$ & The town centre offers a broad range of service stores in the town centre. ${ }^{\mathrm{a}}$ & $3.1(1.7)$ & & $.481 / .183$ \\
\hline Atm & sphere $\left(\xi_{8}\right)$ & & & \\
\hline$x_{81}$ & The odour is not disturbing in the town centre. ${ }^{a^{\dagger}}$ & & & \\
\hline$x_{82}$ & The air is pleasant in the town centre. ${ }^{\mathrm{a} \dagger}$ & & & \\
\hline$x_{83}$ & The temperature is pleasant in the town centre. ${ }^{a^{\dagger}}$ & $42(12)$ & & \\
\hline$x_{84}$ & The light is pleasant in the town centre. ${ }^{a \dagger}$ & $4.2(1.2)$ & & \\
\hline$x_{85}$ & It is always clean in the town centre. ${ }^{\mathrm{a} \dagger}$ & & $.850 / .892$ & $.750 / .506$ \\
\hline$x_{86}$ & The architecture is appealing in the town centre. ${ }^{\mathrm{a}^{\dagger}}$ & & & \\
\hline$x_{87}$ & There is a good mood in the town centre. ${ }^{a}$ & $3.9(1.4)$ & & \\
\hline$x_{88}$ & The atmosphere is pleasant in the town centre. ${ }^{a}$ & $4.0(1.4)$ & & \\
\hline Man & euvrability and Orientation $\left(\xi_{9}\right)$ & & & \\
\hline$x_{91}$ & You can move around without problems in the town centre. ${ }^{\mathrm{a} \dagger}$ & 47 & & \\
\hline$x_{92}$ & You can move around safely and quickly in the town centre. ${ }^{a^{\dagger}}$ & & & $436 / 871$ \\
\hline$x_{93}$ & You can easily orientate yourself within the town centre. ${ }^{a}$ & $5.1(1.2)$ & $.688 / .695$ & $.436 / .8 / 1$ \\
\hline$x_{94}$ & Stores are arranged clearly in the town centre. ${ }^{a}$ & $4.3(1.5)$ & & \\
\hline Infra & structural facilities $\left(\xi_{10}\right)$ & & & \\
\hline$x_{101}$ & There are enough toilets in the town centre. ${ }^{a}$ & $2.3(1.9)$ & & \\
\hline$x_{102}$ & There are enough cash dispensers in the town centre. ${ }^{\text {a }}$ & $4.0(1.6)$ & $.719 / .721$ & $.465 / .724$ \\
\hline$x_{103}$ & There are enough recreational areas in the town centre. ${ }^{a}$ & $3.1(1.8)$ & & \\
\hline
\end{tabular}




\begin{tabular}{|c|c|c|c|c|}
\hline \multicolumn{2}{|c|}{$\begin{array}{l}\text { (latent) Factor } \\
\text { Indicator }\end{array}$} & $\mu(\sigma)$ & $\rho / \alpha$ & AVE/FLR \\
\hline \multicolumn{5}{|c|}{ Satisfaction $\left(\eta_{11}\right)$} \\
\hline$y_{111}$ & How satisfied are you with the town centre (very dis-/-satisfied). & $4.1(1.4)$ & \multirow{3}{*}{$.844 / .848$} & \multirow{3}{*}{$.652 / .255$} \\
\hline$y_{112}$ & How does the town centre meet your expectations (not at all/totally). ${ }^{\mathrm{b}}$ & $3.8(1.5)$ & & \\
\hline & $\begin{array}{l}\text { Think of an ideal town centre/shopping mall. To what extent does the } \\
\text { town centre come close to that? (not close/very close). }\end{array}$ & $3.1(1.7)$ & & \\
\hline \multicolumn{5}{|c|}{ Retention proneness $\left(\eta_{12}\right)$} \\
\hline$y_{121}$ & You are willing to stay in the town centre as long as possible. ${ }^{\mathrm{c}}$ & $3.8(2.7)$ & \multirow{3}{*}{$.756 / .760$} & \multirow{3}{*}{$.518 / .306$} \\
\hline$y_{122}$ & You enjoy spending your time in the town centre. ${ }^{c}$ & $4.8(2.7)$ & & \\
\hline & You plan to do many things here in the town centre today. ${ }^{\mathrm{c}}$ & $4.3(3.0)$ & & \\
\hline \multicolumn{5}{|c|}{ Patronage intention $\left(\eta_{13}\right)$} \\
\hline$y_{131}$ & $\begin{array}{l}\text { Would you recommend the town centre to other persons } \\
\text { (definitely not/definitely yes). }{ }^{d}\end{array}$ & $4.9(2.4)$ & \multirow{3}{*}{$.765 / .793$} & \multirow{3}{*}{$.574 / .290$} \\
\hline$y_{132}$ & $\begin{array}{l}\text { How likely are you to go to the town centre again } \\
\text { (very unlikely/very likely). }\end{array}$ & $7.3(2.2)$ & & \\
\hline$y_{133}$ & $\begin{array}{l}\text { How likely are you to go to the town centre again and buy somenthing } \\
\text { (very unlikely/very likely). }\end{array}$ & $7.1(2.3)$ & & \\
\hline \multicolumn{5}{|c|}{ 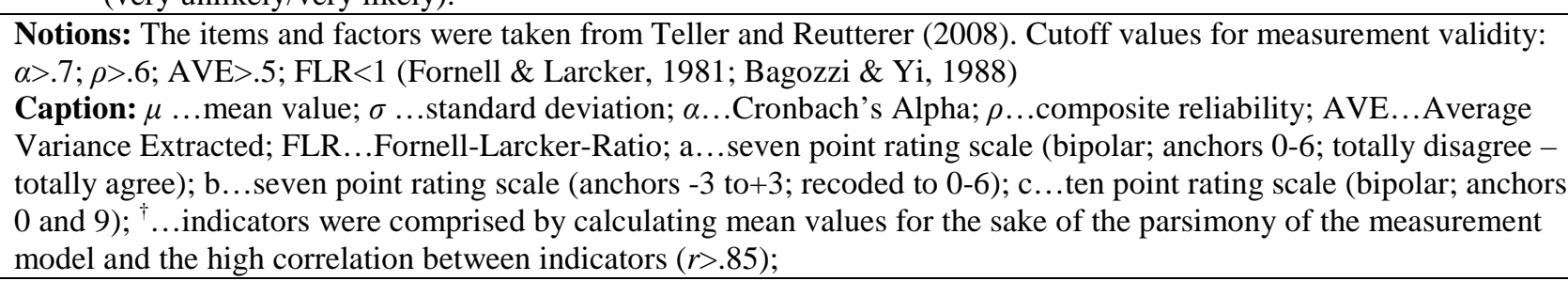 } \\
\hline
\end{tabular}


Figure 1: Conceptual model and proposed effects

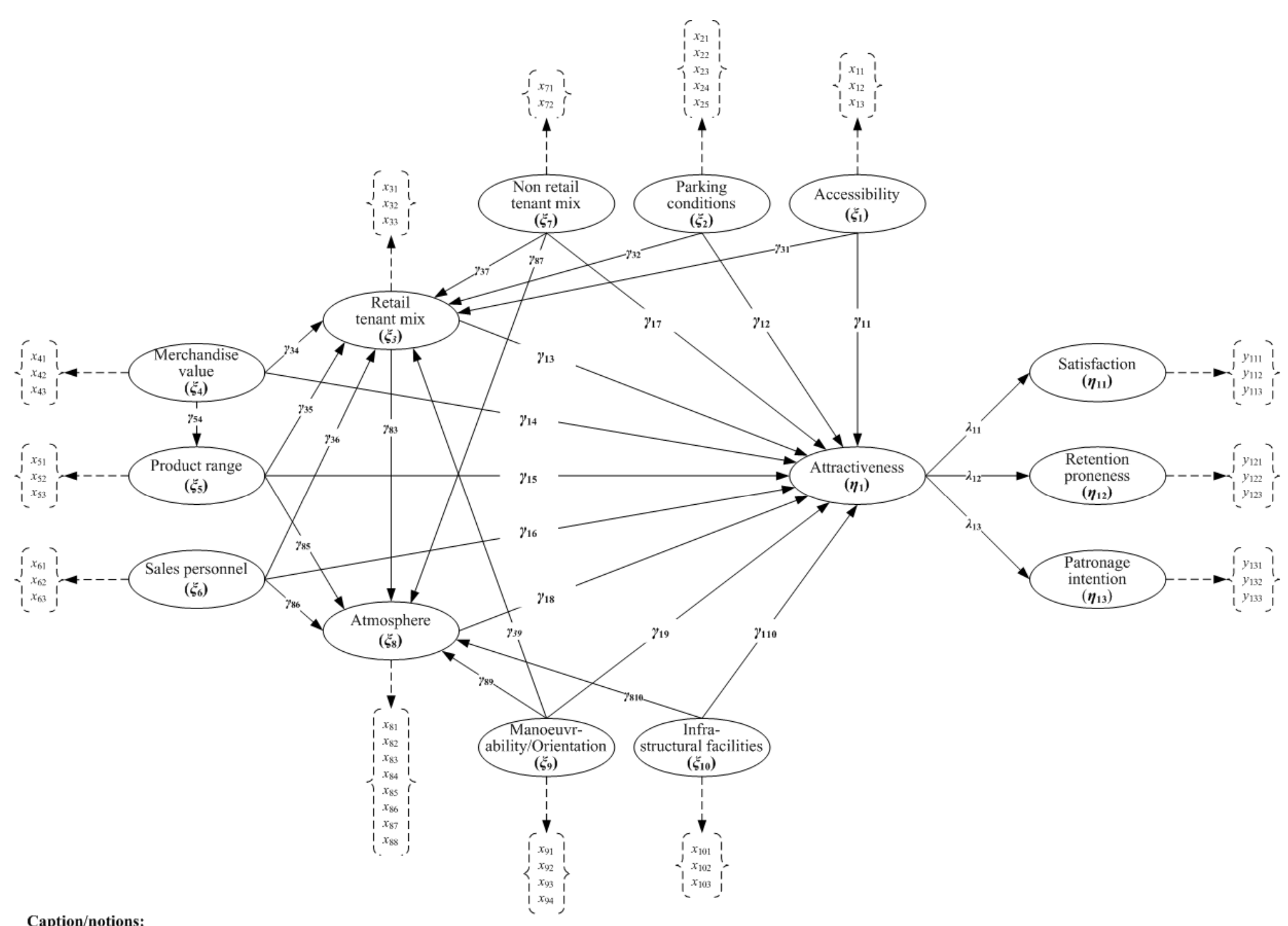

Caption/notions:

${ }_{\mathrm{m}} \ldots$...xogenous factors, $\eta_{\mathrm{n}} \ldots$...ndogenous factors; $\gamma_{\mathrm{mm}} \ldots$ proposed (positive) effects; $\lambda_{\mathrm{n}} \ldots$ factor loadings of second order construct; $x_{\mathrm{m}}, y_{\mathrm{n}} \ldots$..indicators behind factors; inter-correlations between factors $\left(\Phi_{\mathrm{mm}}\right)$ and error terms $\left(\varepsilon_{\mathrm{m}}, \delta_{\mathrm{n}}\right)$ are not shown; 
Table 1: Respondents' profile

\begin{tabular}{|c|c|}
\hline \multicolumn{2}{|c|}{ Demographic characterisation } \\
\hline Gender $[\%]$ & Female, 59.3 \\
\hline Age (years) $[\mu(\sigma)]$ & $29.1(14.7)$ \\
\hline Individual Income (EUR) $[\mu(\sigma)]$ & $975.8(963.5)$ \\
\hline Household income (EUR) $[\mu(\sigma)]$ & $3,136.9(1841)$ \\
\hline Number of persons in household $[\mu(\sigma)]$ & $3.6(1.8)$ \\
\hline Education (Top 3) [\%] & $\begin{array}{l}\text { Secondary school, } 61.1 \\
\text { A-level, } 19.3 \\
\text { Vocational school, } 8.6\end{array}$ \\
\hline \multicolumn{2}{|c|}{ Behavioural characterisation } \\
\hline Shopping (visiting) frequency per month $[\mu(\sigma)]$ & $9.3(8)$ \\
\hline Expenditures on products/services (EUR) per visit $[\mu(\sigma)]$ & $48.8(56.6)$ \\
\hline Expenditures on food/entertainment (EUR) per visit $[\mu(\sigma)]$ & $16.3(26)$ \\
\hline Retention time (min) per visit $[\mu(\sigma)]$ & $109.1(60.7)$ \\
\hline Shops visited per trip on average $[\mu(\sigma)]$ & $3.4(1.8)$ \\
\hline Outshopping tendency (\% of respondents) & 71 \\
\hline Primary visiting task (Top 3) [\%] & $\begin{array}{c}\text { Buying products for themselves, } 40.6 \\
\text { Buying products for someone else, } 40.5 \\
\text { Eating and drinking, } 5.7\end{array}$ \\
\hline
\end{tabular}


Table 2: Direct, indirect and total (standardised) effects

\begin{tabular}{|c|c|c|c|c|c|c|c|c|c|c|c|c|}
\hline \multirow[b]{3}{*}{$\begin{array}{l}\text { Exogenous (affecting) } \\
\text { factors }\end{array}$} & \multicolumn{12}{|c|}{ Affected factors } \\
\hline & \multicolumn{3}{|c|}{$\begin{array}{c}\text { Attractiveness } \\
\left(\eta_{1}\right)\end{array}$} & \multicolumn{3}{|c|}{$\begin{array}{c}\text { Atmosphere } \\
\left(\xi_{8}\right)\end{array}$} & \multicolumn{3}{|c|}{$\begin{array}{c}\text { Retail tenant mix } \\
\qquad\left(\xi_{3}\right)\end{array}$} & \multicolumn{3}{|c|}{$\begin{array}{c}\text { Product range } \\
\qquad\left(\xi_{5}\right)\end{array}$} \\
\hline & $\begin{array}{l}\text { Direct } \\
\text { effects }\end{array}$ & $\begin{array}{l}\text { Indirect } \\
\text { effects }\end{array}$ & $\begin{array}{c}\text { Total } \\
\text { effects }\end{array}$ & $\begin{array}{l}\text { Direct } \\
\text { effects }\end{array}$ & $\begin{array}{l}\text { Indirect } \\
\text { effects }\end{array}$ & $\begin{array}{c}\text { Total } \\
\text { effects }\end{array}$ & $\begin{array}{l}\text { Direct } \\
\text { effects }\end{array}$ & $\begin{array}{l}\text { Indirect } \\
\text { effects }\end{array}$ & $\begin{array}{c}\text { Total } \\
\text { effects }\end{array}$ & $\begin{array}{l}\text { Direct } \\
\text { effects }\end{array}$ & $\begin{array}{l}\text { Indirect } \\
\text { effects }\end{array}$ & $\begin{array}{r}\text { Total } \\
\text { effects }\end{array}$ \\
\hline $\begin{array}{l}\text { Accessibility } \\
\left(\xi_{1}\right)\end{array}$ & $\begin{array}{l}{\left[\gamma_{11}\right]} \\
.038\end{array}$ & $\begin{array}{l}\left\{\xi_{1}\right\} \\
.007\end{array}$ & .045 & -- & $\begin{array}{l}\left\{\xi_{3}\right\} \\
.002\end{array}$ & .002 & $\begin{array}{l}{\left[\gamma_{31}\right]} \\
.013\end{array}$ & -- & .013 & -- & -- & -- \\
\hline $\begin{array}{l}\text { Parking conditions } \\
\left(\xi_{2}\right)\end{array}$ & $\begin{array}{l}{\left[\gamma_{12}\right]} \\
-.069\end{array}$ & $\begin{array}{l}\left\{\xi_{1}\right\} \\
.066\end{array}$ & -.003 & -- & $\begin{array}{l}\left\{\xi_{3}\right\} \\
.016\end{array}$ & .016 & $\begin{array}{l}{\left[\gamma_{32}\right]^{*}} \\
.115^{*}\end{array}$ & -- & $.115^{*}$ & -- & -- & -- \\
\hline $\begin{array}{l}\text { Retail tenant mix } \\
\left(\xi_{3}\right)\end{array}$ & $\begin{array}{l}{\left[\gamma_{13}\right]} \\
.523^{* * *}\end{array}$ & $\begin{array}{l}\left\{\xi_{8}\right\} \\
.046\end{array}$ & $.569^{* * *}$ & $\begin{array}{l}{\left[\gamma_{83}\right]_{*}} \\
.143^{*}\end{array}$ & -- & $.143^{*}$ & -- & -- & & -- & -- & -- \\
\hline $\begin{array}{l}\text { Merchandise value } \\
\left(\xi_{4}\right)\end{array}$ & $\begin{array}{l}{\left[\gamma_{14}\right]^{* * * *}} \\
.376^{* *}\end{array}$ & $\begin{array}{c}\left\{\xi_{3} / \xi_{5}\right\} \\
.207^{*}\end{array}$ & $.584^{* * * *}$ & -- & $\begin{array}{l}\left\{\xi_{3}\right\} \\
.091\end{array}$ & .091 & $\begin{array}{l}{\left[\gamma_{34}\right]} \\
-.049\end{array}$ & $\begin{array}{c}\left\{\xi_{5}\right\} \\
.481^{* * * *}\end{array}$ & $.432^{* * *}$ & $\begin{array}{l}{\left[\gamma_{54}\right]^{* * *}} \\
.775^{* * *}\end{array}$ & -- & $.775^{* * * *}$ \\
\hline $\begin{array}{l}\text { Product range } \\
\left(\xi_{5}\right)\end{array}$ & $\begin{array}{l}{\left[\gamma_{15}\right]} \\
-.061\end{array}$ & $\begin{array}{l}\left\{\xi_{3} / \xi_{8}\right\} \\
.365^{* * * *}\end{array}$ & $.304^{* *}$ & $\begin{array}{l}{\left[\gamma_{85}\right]} \\
.038\end{array}$ & $\begin{array}{l}\left\{\xi_{3}\right\} \\
.089\end{array}$ & .127 & $\begin{array}{l}{\left[\gamma_{35}\right]^{* * *}} \\
.620^{*}\end{array}$ & -- & $.620^{* * * *}$ & -- & -- & -- \\
\hline $\begin{array}{l}\text { Sales personnel } \\
\left(\xi_{6}\right)\end{array}$ & $\begin{array}{l}{\left[\gamma_{16}\right]} \\
.013\end{array}$ & $\begin{array}{c}\left\{\xi_{3} / \xi_{8}\right\} \\
.104^{*}\end{array}$ & $.117^{*}$ & $\begin{array}{l}{\left[\gamma_{86}\right]^{* * *}} \\
.245^{* *}\end{array}$ & $\begin{array}{l}\left\{\xi_{3}\right\} \\
.006\end{array}$ & $.251^{*}$ & $\begin{array}{l}{\left[\gamma_{36}\right]} \\
.045\end{array}$ & -- & .045 & -- & -- & -- \\
\hline $\begin{array}{l}\text { Non retail tenant mix } \\
\left(\xi_{7}\right)\end{array}$ & $\begin{array}{l}{\left[\gamma_{17}\right]} \\
-.074\end{array}$ & $\begin{array}{l}\left\{\xi_{3} / \xi_{8}\right\} \\
.142^{*}\end{array}$ & .068 & $\begin{array}{l}{\left[\gamma_{87}\right]_{* * *}} \\
.142^{* * *}\end{array}$ & $\begin{array}{l}\left\{\xi_{3}\right\} \\
.024\end{array}$ & $.166^{*}$ & $\begin{array}{l}{\left[\gamma_{37}\right]} \\
.171^{* *}\end{array}$ & -- & $.171^{* * *}$ & -- & -- & -- \\
\hline $\begin{array}{l}\text { Atmosphere } \\
\left(\xi_{8}\right)\end{array}$ & $\begin{array}{l}{\left[\gamma_{18}\right]_{* * *}} \\
.321^{* *}\end{array}$ & -- & $.321^{* * *}$ & -- & -- & -- & -- & -- & -- & -- & -- & -- \\
\hline $\begin{array}{l}\text { Maneuverability/orientation } \\
\left(\xi_{9}\right)\end{array}$ & $\begin{array}{l}{\left[\gamma_{19}\right]} \\
-.090\end{array}$ & $\begin{array}{l}\left\{\xi_{3} / \xi_{8}\right\} \\
.163^{*}\end{array}$ & .073 & $\begin{array}{l}{\left[\gamma_{89}\right]_{* * *}} \\
.378^{* * *}\end{array}$ & $\begin{array}{l}\left\{\xi_{3}\right\} \\
.010\end{array}$ & $.388^{* * * *}$ & $\begin{array}{l}{\left[\gamma_{39}\right]} \\
.073\end{array}$ & -- & .073 & -- & -- & -- \\
\hline $\begin{array}{l}\text { Infrastructurel facilites } \\
\left(\xi_{10}\right)\end{array}$ & $\begin{array}{c}{\left[\gamma_{110}\right]} \\
.124 \\
\end{array}$ & $\begin{array}{l}\left\{\xi_{8}\right\} \\
-.009\end{array}$ & .115 & $\begin{array}{l}{\left[\gamma_{810}\right]} \\
-.028\end{array}$ & -- & -.028 & -- & -- & -- & -- & -- & -- \\
\hline \multicolumn{13}{|c|}{$\begin{array}{l}\left.\left[\gamma_{\mathrm{nm}}\right] \ldots \text { proposed direct effects (see figure } 1\right) ;\left\{\xi_{\mathrm{m}}\right\} \ldots \text { mediating factor(s); } * \ldots t \text {-values significant at } p<.05 \text { level; } * * \ldots t \text {-values significant at } p<.01 \text { level; } * * * \ldots t \text {-values significant } \\
\text { at } p<.001 \text { level; --...no (in)direct effect proposed or } \mathrm{n} / \mathrm{a} \text {; } \\
\text { Notions: } \\
\text { This table only shows standardised effects (regression weights); global fit measures (recommended cut-off values in brackets): absolute fit measure: RMSEA }(<.08)=.052 ; \\
\text { incremental fit measures: TLI/CFI }(>.9 />.9)=.914 / .925 ; \text { parsimony fit measures: Normed } X^{2}(C M I N / d f)(<3)=2.319 ; \text { degrees of freedom }(d f)=617 ; \text { squared multiple correlations } \\
\left(r^{2}\right) \text { of } \eta_{1}=.890 ; \xi_{5}=.600 ; \xi_{3}=.634 ; \xi_{8}=.497 ; \text { standardised factor loadings of the second order construct: } \lambda_{11}=.761 ; \lambda_{12}=.534 ; \lambda_{13}=.495\end{array}$} \\
\hline
\end{tabular}

